\title{
Gilt Groupe: Desperately Seeking a New Business Model How Discount Luxury Sites Struggle in the Economic Recovery Era
}

Nikolai Ostapenko

University of the District of Columbia, Washington, USA.

\begin{tabular}{|c|c|}
\hline & ABSTRACT \\
\hline $\begin{array}{l}2016 \text { Research Leap/Inovatus Services Ltd. } \\
\text { All rights reserved. } \\
\text { DOI: } 10.18775 / \text { jibrm.1849-8558.2015.71.3002 } \\
\text { URL: } \frac{\text { http://dx.doi.org/10.18775/jibrm.1849- }}{8558.2015 .71 .3002} \\
\end{array}$ & $\begin{array}{l}\text { Gilt Groupe is a favorite website for luxury bargain hunters spending their lunch breaks with } \\
\text { style. The company, founded in } 2007 \text {, already has a well-established reputation and is expected } \\
\text { to generate close to } \$ 1 \text { billion in annual sales by the end of } 2012 \text {. Its online platform uses the } \\
\text { "flash sales" method, offering limited-time availability of high fashion, travel, home décor, and } \\
\text { culinary bargains to its members. Membership, originally by invitation only, is now open to all. } \\
\text { The idea of moving "sample sales" online was first realized on a European website, Vente- } \\
\text { Privee.com, which now has more than } 13 \text { million customers. Following Gilt's introduction in the } \\
\text { United States, flash sales skyrocketed and led to the launching of many new sites, which have } \\
\text { proved popular both with consumers seeking impressive discounts on uber-luxury goods, and } \\
\text { with exclusive brands wanting to unload their unsold stock quickly. }\end{array}$ \\
\hline
\end{tabular}

\section{Introduction}

Gilt is an interesting case study of a successful, trend-setting player in the ever-challenging fashion industry. After its foundation, the company experienced a meteoric rise in online sales and even approached a possible public offering within its first five years. Yet, as the economy slowly began returning to normal and luxury overstock was less available, Gilt's business model seemed to become more vulnerable than sustainable. That, in combination with the intense influx of competitors, has led Gilt to try a variety of new ideas and new marketing strategies, seeking to build on its strong brand recognition and influx of investor money to expand and grow successfully. This research examines the state of the discount luxury market in the U.S. economy and analyzes Gilt's marketing and operations strategies in this lucrative yet complicated market segment.

\section{Overview of the Discount Luxury Industry}

2.1 Discount Luxury Market and Gilt's Major Competitors Gilt Groupe operates in an extremely competitive market where aggressive competitors fight for the same pool of customers and the same luxury good overstocks from the world's desirable brands. Despite Gilt's pioneering market entrance as the first "flash-sample reseller" on the web platform in the United States, relatively low market entry barriers allowed other sites to quickly get into the game and follow Gilt closely in terms of market size and revenue. The ease with which a website can be set up, without the major overhead costs of luxury brick-andmortar stores, opened the gates to a flood of competitors. The biggest barriers to entry are the lack of available luxury inventory, which affected Gilt as well not long ago, and the desire of the most desirable brands to work only with carefully selected and well- established discount websites. The consequences of these barriers are evident in Gilt's business strategy, as the company constantly tries to innovate by rapidly expanding and enhancing its online offerings and mobile platforms. There are countless competitors emulating Gilt's business model, but we will focus on three major ones.

Because Gilt was the first site of its kind in the United States, its revenue, as demonstrated in Chart 1, has increased rapidly, staying consistently ahead of its competitors. After one year of operation, Gilt earned about \$24 million in revenue. Three years later, that number exploded to $\$ 605$ million, with many analysts believing it will surpass $\$ 1$ billion in 2012 (http://www.ft.com/intl/cms/s/0/124b3b68-1386-11e1-956200144feabdc0.html\#axzz1g9fpbX 1D). Currently, with more than 5 million members, Gilt leads the domestic competition in terms of membership charts as well. Starting with luxury clothing for women, its business has expanded into many other categories, and currently includes men's and children's branded apparel, home and artisan products, fine food and wine, and appealing travel deals. 


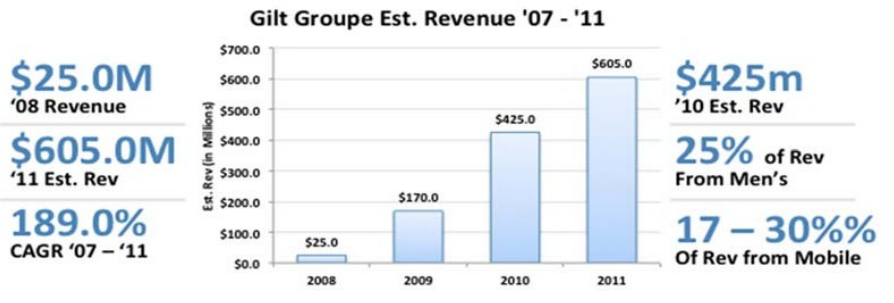

Chart 1: Financial Times,

http://www.ft.com/intl/cms/s/0/124b3b68-1386-11e1-9562

Internationally, Vente-Privee.com was the first company to get into the discount luxury segment online, as early as2001. The company is the only competitor that exceeds Gilt in terms of all major financial indicators. Its membership base of over 13 million customers is almost three times larger than Gilt's. However, the site currently operates only in Spain, Germany, Italy, Austria, the United Kingdom, and Belgium, and thus has not been competing directly for U.S. customers. Potential still exists, owing to close relationships with more than 850 luxury European brands that allow the company to access highly regarded inventory and top-of-the-line products (http://www.forbes.com/sites/matthewcarroll/2012/01/05/therise-of- gilt-groupe-part-3/4/).

RueLaLa (www.ruelala.com) is an American site launched in mid-2008. It has around 450 million members and makes an estimated $\$ 300$ million in revenue by focusing almost exclusively on women's luxury clothing, with occasional offerings of home accessories and men's goods (http://www.forbes.com/sites/matthewcarroll/2012/01/05/therise-of-gilt-groupe- part-3/4/). The company followed Gilt closely in terms of granting "members-only" access, garnered much media attention at a time when the press was focusing on Gilt, and quickly started to share Gilt's reputation and customer base.

Ideeli, another significant competitor, started in 2007, shortly after Gilt came onto the scene. The company has around 4 million members and revenue hovering around $\$ 200$ million (http://www.forbes.com/sites/matthewcarroll/2012/01/05/therise-of-gilt-groupe-part-3/4/).

Ideeli was one of the original competitors to succumb to the high pressure of the online luxury marketplace. The market rule suggests that when more competitors fight for the same inventory, luxury companies experience a decline in overstock and are less interested in reducing the wholesale price. It has become much more difficult to deliver the high end of luxury to consumers at a big discount. The CEO of Ideeli, Paul Hurley, began to move away from top luxury brands, on the theory that "with high-end retail, there's only so much inventory to work with. Scarcity is part of the high-end fashion brands' strategy" (http://www.reuters.com/article/2011/10/17/us-flashsalesidUSTRE79G41X20111017). The company now sells luxury items from the lower end, where the inventory is more readily available and the potential customer base is much larger, albeit less affluent.

\subsection{The Threat from New Market Entrants}

Luckily for Gilt Groupe, the discount luxury market is becoming more difficult to enter with success. Oversaturation of the market led to customer fatigue regarding any new market opportunity, and to a feeling among consumers that they already have enough choices, perhaps even too many, as our survey among young professionals in the Washington, D.C., area suggested. Additionally, strengthening in true luxury sales and abundant demand for overstocked items caused a decline in the inventory available for purchase by new entrants (http://www.reuters.com/article/2011/10/17/us-flashsalesidUSTRE79G41X20111017). The only significant player worth mentioning in this regard is Vente-Privee.com, the European founder of the flash-sales business model. This company's vast market experience and tight relationships with some of the world's most prestigious brands have helped it sustain popularity as it circumvents the scarcity issue. Recently it partnered with American Express, hoping to leverage the latter's 42 million customers for an early influx of American Express card holders (http://www.forbes.com/sites/matthewcarroll/2012/01/05/therise-of-gilt-groupe- part-3/4/).

\subsection{Threat of Market Substitutes}

Substitutes in the discount luxury market come from two main sources. One such source is sites such as Fab.com, which are starting to gain popularity. Fab.com, a flash site similar to Gilt, has become popular because of its highly specialized and preselected unique items that customers could not readily find elsewhere. The site rarely sells clothing items and focuses mainly on high-end non-apparel designs such as visual art, gadgets, and lighting fixtures. It can be considered a substitute because it shows a trend among online consumers to move away from the Gilt business model, which offers a vast array of products that were available in luxury department stores a year ago. The attraction is to a highly curated service that creates the illusion of purchasing something worth buying from a source offering unique designs, rather than just products that used to be available at full price.

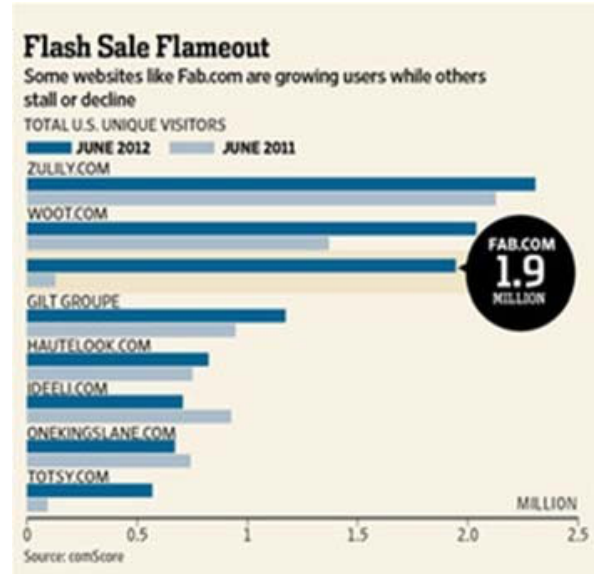

Chart 2: Wall Street Journal

This new format works and, as suggested in Chart 2, more and more consumers are flocking to sites like Fab.com or Woot.com, another site offering one specific unique item a day that typically sells out in just in a few hours, rather than to Gilt, Ideeli, and similar competitors (http://online.wsj.com/article/SB100008723963904440979045 
77535323312754532.html?mo d=googlenews_wsj\#). Gilt's unique visits went up $24 \%$ from the year before to slightly above 1 million, the highest increase among industry competitors. Fab.com, by contrast, increased its unique visits from 129,000 to 2 million: a $16.56 \%$ boost. Obviously a shift is under way, in terms of what kind of "flash sale" site consumers want to spend their time and money on.

The other substitute comes from the full-price luxury market. As the global economy slowly recovers, the luxury goods market is experiencing robust growth. LVMH, owner of Louis Vuitton and other posh brands, recorded net profits up 28 percent in 2011 over 2010, which already was a strong year

(http://view.koreaherald.com/kh/view.php?ud=201207300007 $33 \& c p v=0$ ). PPR, owner of Gucci and Yves Saint Laurent, saw a sales increase of $17 \%$. Jumps in luxury sales across the board reflect an influx of customer spending in designer boutiques and department stores such as Neiman Marcus, Saks Fifth Avenue, Nordstrom, and Bloomingdale's, as well as on their transactional websites. Additionally, Net-a-Porter.com, the most prestigious online seller of full-price luxury goods, has been seeing huge increases in its net profits and importance in the

industry (http://view.koreaherald.com/kh/view.php?ud=201207300007 $33 \& \mathrm{cpv}=0$ ). As consumers are earning more money again, they are willing to step away from discount sites such as Gilt, where they had a chance to buy - and fast - a limited supply of notquite-flashy and possibly ill-fitting merchandise, to full luxury retailers where they can get what they want on their own terms. One of Gilt's core strategies, the "flash sales" model, certainly offers business advantages but forces consumers to respond immediately, and buy before the item is gone forever. With more money in hand, many consumers are more likely to forego this "competitive shopping" opportunity and make more meaningful, thoughtful, and "experiential" purchases at full price in luxury stores.

\subsection{Bargaining Power of Customers}

Customers can exert pressure on Gilt, given the availability of a vast number of competitors offering similar products in a similar format. A customer who is unhappy with Gilt can simply switch to another reseller such as RueLaLa, VentePrivee, or the hundreds of others that have emerged since the rise of Gilt. As Gilt struggles to offer the $70 \%$ discounts of its early days

and increasingly shifts to discounts of $40-50 \%$, consumers are likely to desert and switch to other competitors or substitutes, such as department or specialized stores that offer them exactly what they are looking for. Given the free membership at Gilt and other competitors, switching costs the consumer nothing. Because most customers are highly price-sensitive, they were willing to endure the downsides of Gilt (last season's designs, rushed and competitive shopping) when they were getting impressive discounts, but as discounts lessen and consumers have more discretionary money, they can exercise more power over the company in the marketplace.

\subsection{Bargaining Power of Suppliers}

One of the biggest problems facing Gilt is the power of its suppliers. The founders admit that when starting the site, their greatest difficulty was persuading luxury brands to let them sell goods online at a huge discount (http://online.wsj.com/article/SB100014240527487037927045 $75366842447271892 . h t m l)$. If that was difficult during the recession, it has become even more so as the luxury market strengthens. In Gilt's initial phase, as the recession began to hit luxury brands hard, overstock inventories sometimes ballooned by a factor of ten, to a level totally unfamiliar to these companies (http://www.reuters.com/article/2011/10/17/usflashsales-idUSTRE79G41X20111 017). That led to a situation where Gilt faced "adequate supply, great pricing, and brands willing to talk to them," according to Steven Dennis, founder of Sageberry Consulting, which researches online retail markets (http://www.reuters.com/article/2011/10/17/usflashsales- idUSTRE79G41X20111017). Times have changed, however. Companies have learned to scale down production to avoid such extreme inventory excesses (http://www.businessoffashion.com/2011/12/the-rise-stumbleand-future-of-gilt-groupes-busi ness-model.html). The merchandise stocks that they currently have and are willing to sell also have many potential buyers, as opposed to just Gilt. That has driven wholesale prices up, and Gilt, which averaged $70 \%$ discounts in the beginning, now offers average discounts of $40-50 \%$, with suppliers no longer forced to settle for rock bottom pricing (http://www.reuters.com/article/2011/10/17/usflashsales-idUSTRE79G41X20111017). Even more distressing, suppliers of top luxury brands no longer feel the need to sell to Gilt or other web platforms at all, and that has caused the online selection of brands to suffer. Years ago Gilt was selling brands like Zac Posen and Gucci for women at a discount.

A quick look at the site now shows that many of the brands are ones that most consumers would not readily recognize. The combination of an influx of competitors and a dwindling supply of luxury overstock has allowed suppliers, once grateful price takers, to become price setters (http://www.businessoffashion.com/2011/12/the-rise-stumbleand-future-of-gilt-grou pes-business-model.html). As the economy grows even stronger, luxury brands will want to rebuild their sense of exclusivity by discontinuing, not reselling, their goods. For instance, Lela Rose, a sought-after fashion designer with dresses priced between $\$ 1,000$ and $\$ 10,000$, used to sell her products on Gilt. However, she succinctly expressed suppliers' worries by suggesting, "[Consumers] might be saying, 'That's what I bought when I had no money,' and now they're used to paying the sale price" (http://www.businessoffashion.com/2011/12/the- rise-stumbleand-future-of-gilt-grou pes-business-model.html). But now luxury brands do not worry about customers' willingness to pay full price when they have more money in their pockets.

\section{Marketing Strategies of Gilt \\ 3.1 Product Strategy}

As already stated, Gilt Groupe is an online retail service that brings members discounted luxury goods in a "flash sale" style of shopping experience. Gilt announces upcoming sales via urgent email to all members, and begins selling at noon each weekday, with all merchandise $70 \%$ off the retail price. 


\begin{tabular}{|c|c|}
\hline \multirow[t]{2}{*}{ GILT } & $\begin{array}{l}\text { 50-70\% discounted women's, men's, } \\
\text { children's and babies' clothing, and } \\
\text { home goods }\end{array}$ \\
\hline & $\begin{array}{l}\text { Slightly discounted or full priced local } \\
\text { and artisan food and wine generally } \\
\text { previously only available to chefs }\end{array}$ \\
\hline GILT CITY & $\begin{array}{l}\text { Discounted city specific experiences } \\
\text { such as spas, restaurants, and gym } \\
\text { classes in major metropolitan areas } \\
\text { (competes with groupon etc.) }\end{array}$ \\
\hline \multirow[t]{2}{*}{ JETSETTER } & $\begin{array}{l}\text { A travel site offering both "flash } \\
\text { sales" at discounts and full priced } \\
\text { travel experiences. }\end{array}$ \\
\hline & $\begin{array}{l}\text { A standalone retail site offering } \\
\text { luxury goods for men at full price. } \\
\text { Offers a curated selection of men's } \\
\text { latest fashions }\end{array}$ \\
\hline
\end{tabular}

Figure 1: Presented by using logos from Gilt's sites

Most sales last for 36 hours, but merchandise often sells out sooner, given the limited quantity and the high demand. In fact, over $50 \%$ of revenue comes within one hour of the start of the sale

(http://www.forbes.com/sites/matthewcarroll/2012/01/05/therise-of-gilt-groupe-part- 3/4/). This sense of urgency is a huge part of what makes Gilt so successful, and it is a key part of the product and promotion strategies. Consumers get on the site and recognize that they have a very limited amount of time to get products at steep discounts before they are gone. Thus they are much more likely to make impulse purchases, and they lack the luxury of time to weigh their options. Initially, Gilt started these flash sales only for women's clothing and only for a small membership base: originally, 15,000 members personally invited by Gilt's founders, Alexis Maybank and Alexandra W. Wilson

(http://online.wsj.com/article/SB100014240527487037927045 75366842447271892.html). As the business grew, however, Gilt's product changed to include many more services, as well as unrestricted membership. These changes began around the time of the launch of Gilt Man site, the same business model selling men's clothing and accessories. Figure 1 shows Gilt's current full range of product lines. Obviously the brand has expanded far beyond women's clothing, and now offers a variety of products at a range of discounts. All the sites have a very luxurious visual appearance, featuring black backgrounds and highly styled professional photos. They also are curated to suggest that customers are getting a selection of only the best products, and Gilt's latest endeavor, Park and Bond, has largely separated itself from the Gilt brand name altogether.

\subsection{Price Strategy}

Gilt's pricing is one of the most important factors in the rise of the brand image. Gilt Groupe's "bread and butter," Gilt.com, offers women's, men's, and children's clothing, as well as home decor and gifts, at between 50 and $70 \%$ off retail prices. Additionally, selling to Gilt gives sellers an opportunity for a quick influx of cash, always welcomed by many smaller brands and frequently helpful to almost all brands in the depths of the recession. Gilt typically buys the product at $50 \%$ off wholesale price. As retailers typically markup clothing from the price they have paid, the wholesale price equals half of the retail price. By purchasing at half the wholesale price, Gilt can double the price it pays and still sell at $50 \%$ off the retail price. When purchasing extra-large orders, Gilt can get goods even lower, at less than $50 \%$ of the wholesale price, and thus can offer discounts in the $70 \%$ range (http://www.forbes.com/sites/matthewcarroll/2012/01/05/therise-of-gilt-groupe-part-3/4/).

Some of their other product lines offer smaller or no discounts: Park and Bond offers no discounts, Jetsetter offers some fullprice travel packages, and Gilt Taste offers limited discounts, if any. They justify these full prices by offering very exclusive selections of goods, to give members the additional benefit of seeing only the crème de la crème of men's clothing, travel experience, and artisan food and wines, respectively.

\subsection{Place Strategy}

Gilt has always excelled in the "place" arena. Its storefront is completely online and therefore open $24 / 7$ to customers. Its website is a case study in exuberant elegance and sophistication. The site is divided into different categories by tabs at the top, allowing members to look only at the sales relevant to them. Most men, for example, have no need to see the newest women's sales, and upon login are immediately directed to the Gilt Man dedicated section. The photography is extremely professional, and the cover photos for the sales look more like the ads in glossy magazines than the photos typically found on a retailer's website, whether discount or full-price.

Additionally, Gilt put a strong early effort into developing dedicated mobile applications so that consumers can shop on the fly. Given the urgency of the flash sales, which start promptly at 12 p.m., the mobile app allows customers who may not have computer access at the moment to quickly get on their iPhones, iPads, Blackberries, or Androids and rapidly browse the site. As seen in Chart 1, up to $30 \%$ of Gilt's revenues come from purchases via mobile apps. Even more extraordinary, Gilt sees up to $50 \%$ of its revenues coming from the apps on holiday weekends, such as July 4th, when consumers are traveling or on the beach and do not necessarily have access to computers (http://bits.blogs.nytimes.com/2012/06/29/gilt-groupemobile/). Gilt also innovates constantly in the mobile arena. A new version of the app will allow customers to upload photos of themselves and then "try on" items like sunglasses (http://bits.blogs.nytimes.com/2012/06/29/gilt-groupemobile/). While that may sound gimmicky, it gets consumers excited to get on the app and try it, and, of course, more customers lead to more sales.

One weakness worth mentioning is the occasional problem of the website's functionality. When there is a highly publicized and desirable sale, as when the site offered Christian Louboutin or vintage Hermès bags, the site crashes or is extremely slow. Given the limited quantities and the first-come-first-served nature of flash sales, this can be problematic for customers who are set on a product but find that it has sold out by the time the page loads. With the exception of this infrequent problem, Gilt's accessibility is one of its greatest strengths.

\subsection{Promotion Strategy}


Gilt's promotion has been widely talked about in the media because its marketing has stayed "under the radar," without any advertising campaigns or commercials. Additionally, the company's intense focus on gaining a desirable membership base helped spread the word to affluent customers and helped reassure luxury brands that Gilt was protecting their exclusivity. Once the site had funding and was up and running, the founders sent out invitations to 15,000 of their colleagues from the Harvard Business School, friends from their undergraduate-degree universities, and fashion industry gurus from whom they gained retail and business experience (http://online.wsj.com/article/SB100014240527487037927045 75366842447271892.html).

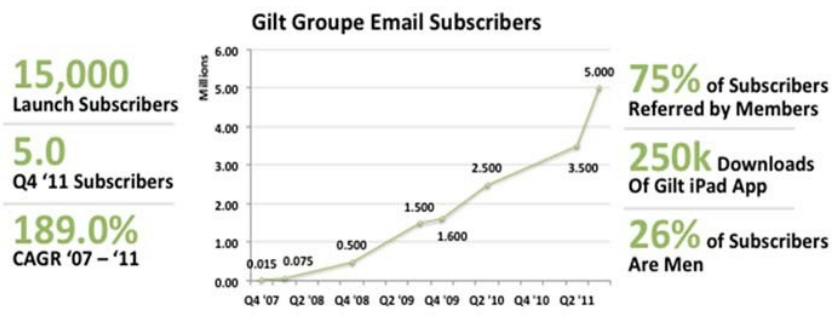

Chart 3: Forbes

They targeted this market because these people were exactly the demographic they hoped to reach: wealthy, educated, and young, like the founders themselves. From there, the only way to gain membership was by referral from an existing member, who got a \$25 gift certificate for inviting friends. It was an ingenious way to gain members, as all the new members were connected with the initial group of highly desirable customers. The strategy paid off in spades. As seen in Chart 3, membership skyrocketed, with more than $75 \%$ of subscribers referred to the website by members (http://www.forbes.com/sites/matthewcarroll/2012/01/05/therise-of- gilt-groupe-part-3/4/). Now, with over 5 million members, Giltworks with the exact demographics that it initially desired. Customers are young, rich, and educated; $65 \%$ are younger than $35 ; 67 \%$ have an income in excess of $\$ 150,000$; and $87 \%$ have bachelor's degrees (http://www.forbes.com/sites/matthewcarroll/2012/01/05/therise-of-gilt-groupe-part- 3/4/). The founders were also wise to make themselves the "face" of the company. They are goodlooking, young, and smart, and they felt that including personal notes in all packages and emailing members to offer personal selections would make their company more relatable. As they said in their book, "We knew that increasing our visibility would help us personalize and build trust in the brand. Gilt wouldn't be a faceless corporate behemoth like most online retailers. Instead, it would have a friendly human face, despite being a brand most customers interact with only via their computers" (Maybank and Wilkinson, 2012).

Guilt owners also went on a "tour" of sorts by holding upscale events whenever they traveled to a new place, and hosting private dinners for Gilt's most loyal customers, as well as bloggers, journalists, and tastemakers. They followed up by sending handwritten notes to those whom they had met and, as a result, they were featured in countless media pieces across the country (Maybank and Wilkinson, 2012). Their marketing strategy was a smart way to grow both the company and its aura of brand exclusivity. By deciding to offer membership to a limited group at first, they were able to avoid overwhelming the site and to grow slowly and consistently, while building a base of loyal customers.

\section{Conclusion}

Gilt has many challenges in the years ahead, as well as many undiscovered opportunities. For one thing, the business of flash sales, with its dwindling suppliers, is responsible for only 35$50 \%$ of Gilt's total business today. Now designers are being asked to make inventory especially for Gilt, goods never available in stores, using the designer's own extra fabrics and supplies. This opens up for Gilt a whole new market that nobody else has been thinking about (Thau). Thus the company can offer new, exclusive goods while still ensuring a great online discount.

Gilt should also continue to expand its full-price brands. Park and Bond has had great success in selling high-priced men's clothing, and such an opportunity also exists for women's apparel. Gilt's competitor Net-a-Porter has become an icon, creating a market for luxury women's online retailing that did not exist before. With only one other major player in the highend luxury brands, Gilt can tap its resource of vendors and brand relationships in that market.

Gilt's services, already top-notch, can be translated into quality media editorial content on fashion, which gives full-price customers added value and reason to shop. Park and Bond has already teamed up with men's magazine GQ to offer "Editor's Selections" and editorial content, which immediately gives Park and Bond a share in GQ's excellent reputation for men's style. Gilt Taste has partnered with Gourmet Magazine for a similar reason and hired Ruth Reichl, one of the country's most respected food critics, to provide editorial content and recommendations for the foods they sell. That gives consumers confidence, and gives Gilt Taste brand equity by relating it to such a respected fashion magazine (http://techcrunch.com/2011/05/18/gilt-taste-a-pricey-onlinemarketplace-for-artisan-foods/).

Continuing to build connections with great magazines and brands will help spread the word about Gilt, and it will give consumers the added benefit of top-quality publicity when shopping for Gilt brands.

Gilt also has global opportunities that it is just beginning to explore. If it is successful, the growth potential overseas is obviously enormous, so it is crucial that the company expand carefully and thoughtfully. Gilt is offering free international shipping and returns for a limited time to entice new customers in many countries to try its products. The company is working diligently to master the intricacies of international shipping, going as far as to call it "step number one in going global," so that it can understand the international market (http://www.ft.com/intl/cms/s/0/124b3b68-1386-11e1-956200144feabdc0.html\#axzz1g9fpbX 1D). It must look into partnerships abroad, so that it can work with successful 
businesses, possibly acquire the companies of possible competitors, and instantly become a large presence abroad.

Finally and less obviously, Gilt needs to leverage its immense customer research tools. The company has been collecting customer data since its inception. It looks at everything from age and gender to the types of products customers buy and how to customize the email message each user gets daily so that it displays only the sales most relevant to the user in question (http://www.businessoffashion.com/2011/12/the-rise-stumbleand-future-of-gilt-groupes-busi ness-model.html). If it shares this information with its vendors and partners, it will be able to

leverage this data into a significant cash flow as well as to revitalize the relationships with some of the luxury vendors that no longer work with the company (http://www.ft.com/intl/cms/s/0/124b3b68-1386-11e1-956200144feabdc0.html\#axzz1g9fpbX ID).

The company obviously has been extremely successful by searching for opportunities everywhere and seizing them. As the market changes, the company has enough drive, intelligence, money, and prospects to adapt successfully to the new economic situation and continue to run an innovative fashion business model on a global scale.

\section{References}

1. Barr, A. (17.10.2011). Online flash sales less flashy as inventory shrinks. Reuters. Retrieved from http://www.reuters.com/article/2011/10/17/ us-flashsales- idUSTRE79G41X20111017.

2. Barr, A. (2012). Gilt's main flash sales profitable. Retrieved from http://www.reuters.com/article/2012/06/07/gi lt-profitable-idUSL1E8H7DRD20120607.

3. Bradshaw, T., Moules, J. and Barney, J. (2011). Gilt Groupe consider going public in 2012. Financial Times. Retrieved from http:/www.ft.com/intl/cms/s/0/124b3b68138611e1-956200144feabdc0.html\#axzz1g9fpbXID.

4. Business of Fashion. (15.12.2011). The Rise, Stumble, and Future of Gilt Groupe's Business Model. Retrieved from http://www.businessoffashion.com/2011/12/t he-rise- stumble-and-future-of-gilt-groupesbusiness-model.html.

5. Carrol, M. (2012). The Rise of Gilt Groupe: The Great Recession Fuels the Perfect Storm. Retrieved from http://www.forbes.com/sites/matthewcarroll/ 2012/01/05/the-rise- of-gilt-groupe-part-3/4/.

6. Chen, B. (2012). Gilt Groupe's Recipe for Success in Mobile. New York Times. Retrieved from http://bits.blogs.nytimes.com/2012/06/29/gilt -groupe-mobile/.
7. Debaise, C. (19.10.2010). Launching Gilt Groupe, a Fashionable Enterprise. Wall Street Journal. Retrieved from, http://online.wsj.com/article/SB10001424052 748703792704575366842447271892.html.

8. Dishman, L. (09.08.2011). Gilt Groupe Targets Guys for New Luxury Retail Site Park \& Bond. Retrieved from http://www.forbes.com/sites/lydiadishman/20 11/08/09/gilt-groupe- targets-guys-for-newluxury-retail-site-park-bond/.

9. Maybank, A. and Wilkinson, A. (2012). By Invitation Only: How We Built Gilt and Changed the Way Millions Shop. New York: Portfolio/Penguin.

10. Odell, A. (20.01.2012). Reports: Layoff at GilrGroupe Today. New York Magazine. Retrieved from http://nymag.com/daily/fashion/2012/01/repo rts-gilt-laid-off-more-than- a-hundredtoday.html.

11. Rao, L. (18.05.2011). Gilt Taste: A Pricey Online Marketplace for Artisanal Foods. Tech Crunch. Retrieved 10.12.2011 from http://techcrunch.com/2011/05/18/gilt-tastea-pricey- online-marketplace-for-artisanfoods/.

12. Rice, A. (14.02.2010). What's a Dress Worth? New York Magazine. Retrieved from http://nymag.com/print/?/fashion/10/spring/6 $3807 /$.

13. Sherman, L. (31.01.2008). By Invitation Only. Forbes. Retrieved from http://www.forbes.com/forbes/2008/0225/07 0.html.

14. Spencer, A. (19.07.2012). Are Sites Still 'Fabulous?. Retrieved from http://online.wsj.com/article/SB10000872396 390444097904577535323312754532.html? mod=googlenews_wsj\#.

15. The Korea Herald. (30.07.2012). Luxury Goods Buck Global Economic Slowdown. Retrieved from http://view.koreaherald.com/kh/view.php?ud $=20120730000733 \& \mathrm{cpv}=0$. 